\title{
A preliminary review of Indonesian national standard of chair and desk for junior high school level
}

\author{
Yanto $^{1,2, *}$, Chih-Wei Lu ${ }^{2}$, Winda Y. Caroline ${ }^{1}$ \\ ${ }^{1}$ Department of Industrial Engineering, Faculty of Engineering, Atma Jaya Catholic University of \\ Indonesia, 12930 Jakarta, Indonesia. \\ ${ }^{2}$ Department of Industrial and Systems Engineering, Chung Yuan Christian University ${ }^{\mathrm{b}}$ \\ 200 Chung Pei Rd, 32023, Chung Li District, Taoyuan City, Taiwan, ROC.
}

\begin{abstract}
This study was a preliminary review to evaluate the dimensions of Indonesian national standard of chair and desk for junior high school level. The furniture was evaluated for seat height, seat depth, seat width, backrest height, desk height and underneath desk height. A number of 301 students were measured for their dimensions. Six equations were used to evaluate the match or mismatch between students' dimensions and dimensions of chair and desk. Results showed mismatch between students' dimensions and the dimensions of chair and desk as issued by the National Standardization Agency of Indonesia. The results of this preliminary review could be a basis for a larger study which covers more samples and geographical areas.
\end{abstract}

\section{Introduction}

School furniture is a key factor for the adoption of proper posture and consequently, greater productivity for the individual [3]. Due to its important, many countries issued their national standard to determine the dimensions of school furniture which could match with majority of students within population. In Indonesia, National Standardization Agency of Indonesia issued the Indonesian National Standard SNI 7555.12-2011 [7][8] which determine the characteristics and dimensions of chair and desk for junior high school level. Based on preliminary field observation, these standards were apparently too high for the majority of students. It seems that these standards were lack of anthropometric consideration.

Recently, [12] has given attention to evaluate the national standard of Indonesian school furniture for elementary school level. Findings in this study [12] revealed that majority of the elementary school students' samples were inappropriate with the current dimensions of national standard for school furniture. Meanwhile, no study has been carried out to investigate whether the current national standards are appropriate for the junior high school students. Hence, the aim of this study was to examine whether the standard dimensions of chair and desk s which were issued by National Standardization Agency of Indonesia match with the anthropometric dimensions of junior high school students.

*Corresponding author: yantoatma@yahoo.com 


\section{Methodology}

\subsection{Samples}

To get the samples, a cross-sectional study was conducted using a convenience sampling technique. The samples in this study involved a group of junior high school students with ages ranging from 12 to 16 years old, Grade 7 to Grade 9. They were selected from 10 junior high schools in Metropolitan City Jakarta, Indonesia. The samples consisted of 301 volunteer students (153 boys and 148 girls), presented in Table 1.

Table 1. Sample distribution of junior high school students in this study.

\begin{tabular}{|l|l|l|l|l|}
\hline & G7 & G8 & G9 & Subtotal \\
\hline Boys (B) & 62 & 57 & 34 & 153 \\
\hline Girls (G) & 52 & 59 & 37 & 148 \\
\hline Subtotal & 114 & 116 & 71 & 301 \\
\hline
\end{tabular}

\subsection{Chair and desk dimensions}

In Indonesia, SNI 7555.12-2011 and SNI 7555.11-2011 were issued as guidelines to determine dimensions of chair and desk for junior high school level. The dimensions of chair and desk taken were the following: seat height, seat depth, seat width, backrest height, desk height and underneath desk height [4][10][11][12], illustrated in Figure 1.
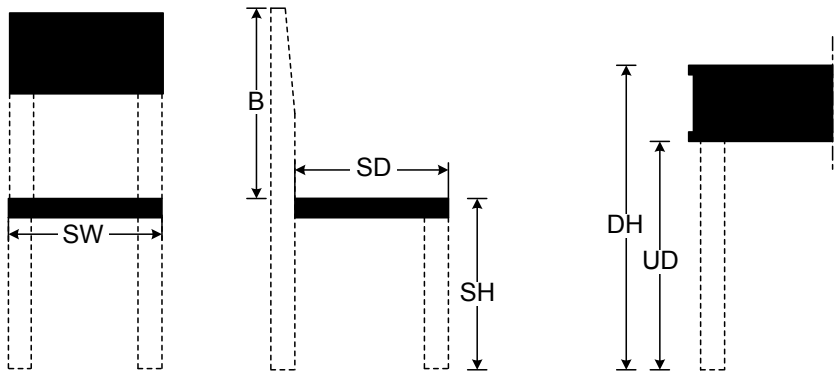

Fig. 1. Representation of the dimensions of chair and desk.

(Source: [12])

\subsection{Junior high school students' dimensions}

For evaluation of school furniture, a few anthropometric dimensions were identified and measured. All anthropometric dimensions were measured with the students in the sitting posture (except for stature). Body dimensions, landmarks and the measurement of each body dimension procedures were defined by [9], Figure 2 . 


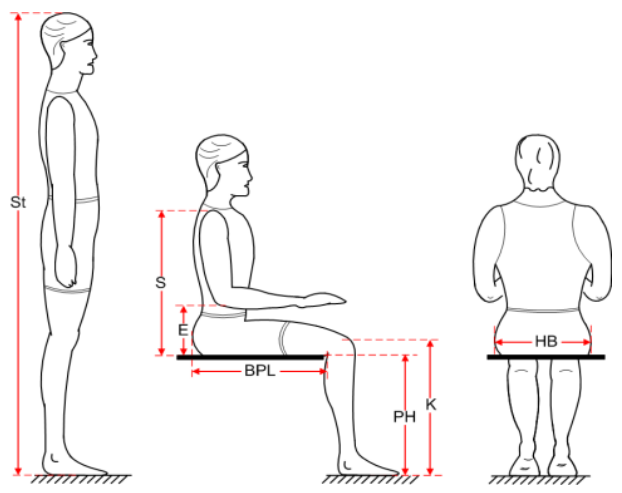

Fig. 2. Illustration of anthropometric measurements of junior high school students.

\subsection{Match or mismatch criteria between students' dimensions and the dimensions of chair and desk}

A few researchers have proposed equations to evaluate school furniture dimensions based on anthropometric dimensions of students. Based on the previous works [10][11] a "mismatch" was defined as incompatibility between the school furniture dimensions and the dimensions of the student's body. In this study, anthropometric dimensions of students were compared with the dimensions of the chair and desk to identify a match or a mismatch between them. Six match criterions were defined according to previous works [2][4][10], presented in Table 2. Regarding the equations in the Table 2, [12] defined a "match" when the dimension of current national standard falls between the minimum limit and the maximum limit for two-way criteria (i.e Equations (1), (2), (4) and (5)), or is greater than or equal to the minimum limit for one-way criteria (i.e Equation (3) and Equation (6)). Meanwhile, a "mismatch" was defined when the dimension of current national standard is greater than the maximum limit or smaller than the minimum limit for two-way criteria, or smaller than the minimum limit for one-way criteria [12].

Table 2. Summary of the dimensions of chair and desk through the mis/match equations.

\begin{tabular}{|c|c|c|c|c|c|}
\hline \multirow[b]{2}{*}{ Chair } & \multicolumn{2}{|c|}{$\begin{array}{l}\text { Relevant product } \\
\text { dimensions }\end{array}$} & (mis)/Match equation & \multicolumn{2}{|c|}{$\begin{array}{l}\text { Relevant } \\
\text { anthropometric } \\
\text { dimensions }\end{array}$} \\
\hline & $\mathrm{SH}$ & Seat height & 1. $\begin{array}{l}(P H+2) \operatorname{Cos} 30^{\circ} \leq S H \leq \\
(P H+2) \operatorname{Cos} 5^{0}\end{array}$ & PH & Popliteal height \\
\hline & $\mathrm{SD}$ & Seat depth & $\begin{array}{ll}2 . & 80 \% B P L \leq S D \leq \\
& 95 \% B P L\end{array}$ & BPL & $\begin{array}{l}\text { Buttock-popliteal } \\
\text { length }\end{array}$ \\
\hline & SW & Seat width & $110 \% H B \leq S W$ & $\mathrm{HB}$ & Hip Breadth \\
\hline & $\mathrm{B}$ & Backrest height & 4. $\quad 60 \% S \leq B \leq 80 \% S$ & $\mathrm{~S}$ & Shoulder height \\
\hline \multirow[t]{2}{*}{ Desk } & DH & Desk height & $\begin{array}{ll}\text { 5. } & S H+E H S \leq S H \leq S H+ \\
& E H S+5\end{array}$ & $\mathrm{E}$ & Elbow rest height \\
\hline & UD & $\begin{array}{l}\text { Underneath } \\
\text { desk height }\end{array}$ & 6. $\quad K+2 \leq U D$ & $\mathrm{~K}$ & Knee height \\
\hline
\end{tabular}




\section{Results}

\subsection{The chair and desk dimensions of national standard for junior high school}

Table 3 presents the standard dimensions of chair and desk for junior high school as issued by the National Standardization Agency of Indonesia [7][8]. The SNI 7555.12-2011 determines the dimensions of chair for junior high school level while the SNI 7555.112011 determines the dimensions of desk.

Table 3. The dimensions of national standard of chair and desk (in $\mathrm{cm}$ ).

\begin{tabular}{|l|l|r|}
\hline $\begin{array}{l}\text { Indonesian National } \\
\text { Standard }\end{array}$ & Furniture dimensions & Dimension \\
\hline Chair & Seat Height (SH) & $42-46$ \\
(SNI 7555.12-2011) & Seat Depth (SD) & $40-50$ \\
& Seat Width (SW) & $40-42$ \\
& Backrest Height (B) & $30-40$ \\
\hline Desk & Desk Height (DH) & $69-75$ \\
(SNI 7555.11-2011) & Underneath Desk Height (UD) & $57-66$ \\
\hline
\end{tabular}

\subsection{Junior High School Students' dimensions}

Table 4 shows the mean, Standar deviation (SD) and percentile values of body dimensions of junior high school students from Grade 7-9 for boys and girls. Based on Table 4, the data show a consistent increase in mean by grade and gender which were supported by results of Anova test. Anova tests showed significant differences among students' grade levels in stature for boys $(\mathrm{F}=21.22 ; \mathrm{p}$-value $=0.000)$ and girls $(\mathrm{F}=12.20 ; \mathrm{p}$-value $=0.000)$, and in popliteal height for boys $(\mathrm{F}=7.33$; $\mathrm{p}$-value $=0.001)$ and girls $(\mathrm{F}=2.29$; $\mathrm{p}$-value $=0.105)$.

Table 4. Anthropometric measures of junior high school students in Grades 7-9 (in cm).

\begin{tabular}{|c|c|c|c|c|c|c|c|c|c|c|c|c|c|}
\hline \multirow{2}{*}{$\begin{array}{l}\text { Anthropometric } \\
\text { dimensions }\end{array}$} & \multirow{2}{*}{ Gender } & \multicolumn{4}{|c|}{ Grade 7} & \multicolumn{4}{|c|}{ Grade 8} & \multicolumn{4}{|c|}{ Grade 9} \\
\hline & & Mean & SD & P5 & P95 & Mean & $\mathrm{SD}$ & P5 & P95 & Mean & $\mathrm{SD}$ & P5 & P95 \\
\hline \multirow{2}{*}{ Stature } & Boys & 155.8 & 8.6 & 143.2 & 171.8 & 158.8 & 6.3 & 150.5 & 168.7 & 166.0 & 6.2 & 158.1 & 175.7 \\
\hline & Girls & 153.4 & 4.6 & 147.2 & 161.2 & 157.0 & 3.5 & 151.5 & 162.2 & 158.6 & 3.6 & 153.7 & 164.9 \\
\hline \multirow{2}{*}{$\begin{array}{l}\text { Sitting shoulder } \\
\text { height }\end{array}$} & Boys & 56.5 & 5.5 & 47.4 & 66.3 & 56.5 & 5.1 & 48.7 & 64.6 & 58.8 & 3.8 & 53.7 & 64.3 \\
\hline & Girls & 54.6 & 3.3 & 50.1 & 60.4 & 55.9 & 2.9 & 51.3 & 60.4 & 56.6 & 3.4 & 52.0 & 61.5 \\
\hline \multirow{2}{*}{ Sitting elbow height } & Boys & 23.5 & 3.7 & 16.6 & 28.8 & 23.2 & 4.3 & 16.3 & 29.4 & 25.1 & 2.9 & 19.9 & 28.9 \\
\hline & Girls & 22.3 & 2.8 & 18.1 & 27.1 & 23.6 & 2.5 & 19.4 & 27.6 & 24.2 & 2.2 & 20.8 & 27.2 \\
\hline \multirow{2}{*}{ Popliteal height } & Boys & 36.3 & 2.1 & 33.1 & 39.2 & 36.7 & 2.6 & 32.6 & 41.0 & 38.0 & 1.5 & 35.9 & 40.6 \\
\hline & Girls & 35.4 & 1.8 & 32.9 & 38.1 & 35.9 & 1.8 & 33.2 & 38.5 & 36.2 & 1.8 & 33.2 & 39.1 \\
\hline \multirow{2}{*}{ Buttock-knee height } & Boys & 48.8 & 1.8 & 46.1 & 51.4 & 49.0 & 2.2 & 45.8 & 52.4 & 49.5 & 1.9 & 47.0 & 52.7 \\
\hline & Girls & 47.2 & 2.0 & 43.4 & 49.8 & 47.7 & 1.9 & 44.7 & 50.3 & 47.4 & 2.2 & 44.1 & 50.4 \\
\hline \multirow{2}{*}{$\begin{array}{l}\text { Buttock-popliteal } \\
\text { length }\end{array}$} & Boys & 40.5 & 2.6 & 36.2 & 44.4 & 40.9 & 2.9 & 35.2 & 44.8 & 41.6 & 2.3 & 37.8 & 44.9 \\
\hline & Girls & 39.9 & 2.6 & 35.5 & 43.9 & 40.5 & 2.7 & 36.3 & 44.5 & 41.4 & 2.5 & 36.5 & 44.5 \\
\hline \multirow{2}{*}{ Hip Breadth } & Boys & 32.6 & 3.9 & 26.7 & 38.2 & 30.9 & 3.6 & 26.1 & 36.7 & 32.5 & 3.2 & 27.3 & 38.4 \\
\hline & Girls & 31.7 & 2.6 & 27.5 & 35.8 & 33.3 & 3.6 & 28.2 & 39.1 & 33.8 & 2.9 & 30.3 & 38.8 \\
\hline
\end{tabular}

\subsection{Mismatch between the dimensions of chair and desk and students' dimensions}

The percentages of junior high school students whose body dimensions did not match with the dimensions of chair and desk were presented in Figure 3 and Figure 4. As can be seen in Figure 3.a, for the lower limit of seat height $(42.0 \mathrm{~cm})$, the current national standard dimension for seat height mismatched for most students from Grade 7-9. For the upper limit of seat height $(46.0 \mathrm{~cm})$, no student matched with that dimension of either Grade 7, Grade 8 
or Grade 9 (100.0\% mismatch). Figure 3.b shows the percentage of mismatch between the seat depth and students' buttock-popliteal length. Based on Figure 3.b, most students were not appropriate with that dimension $(40.0 \mathrm{~cm})$. For the upper limit $(50.0 \mathrm{~cm})$, all students from Grades 7-9 did not match with the current dimension. As for the lower limit of seat width $(40.0 \mathrm{~cm})$, Figure 3.c shows that most of students were appropriate with the current dimension of national standard. Particularly, the dimension of seat width was appropriate for all girls in Grade 7. For the upper limit of seat width $(42.0 \mathrm{~cm})$, most of students were also appropriate with the current dimension. For backrest height, the lower limit dimension of national standard $(30.0 \mathrm{~cm})$ was inappropriate majority of students at all level. Meanwhile, the upper limit dimension of national standard for backrest height $(40.0 \mathrm{~cm})$ was also inappropriate small percentage of students from Grade 7-9.

Figure 4 shows the percentages of mismatch for desk height by gender and grade. The lower limit for desk height $(69.0 \mathrm{~cm})$ was inappropriate for small percentage of students. Meanwhile, the upper limit dimension $(75.0 \mathrm{~cm})$ was inappropriate for the majority of students. As for the underneath height of desk, both lower and upper limit dimensions (57 $\mathrm{cm}$ and $66 \mathrm{~cm}$ ) are appropriate for students at all grades.

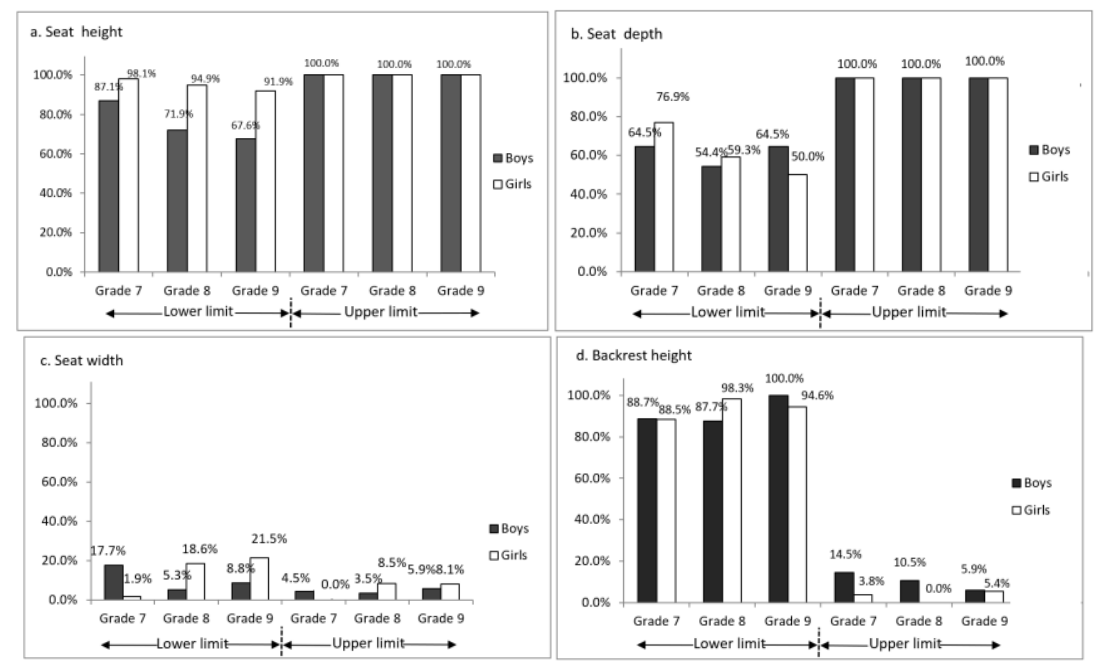

Fig. 3. The percentages of mismatch for the national standard dimensions of chair .

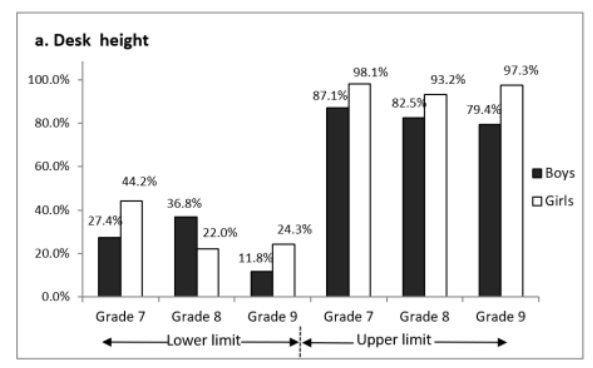

Fig. 4. The percentages of mismatch for the standard dimensions of desk height. 


\section{Discussion}

In this study, results showed mismatch between dimensions of students and the dimensions of chair and desk as issued by the National Standardization Agency of Indonesia. For chair, majority of junior high school students did not match with seat height, seat depth and backrest height. Meanwhile for desk, majority of junior high school students did not match with desk height. The results indicated that the dimension of seat height is too high for majority of students for lower limit and for all students for upper limit. Based on findings from [12], the seat height which is too high cause students' feet will not have proper contact with the floor. This situation may cause the underside of the thigh become compressed causing discomfort and restriction in blood circulation [10]. The results also indicated that the dimension of seat depth is too deep for the students. According to [10], if the seat depth is too deep, the front edge of the seat will press into the area right behind the knees, cutting off circulation to legs and feet. For seat width, the results indicated that the dimension of seat width is appropriate for the majority of the junior high school students. For backrest height, the results indicated that the lower limit dimension of seat width is inappropriate for the majority of the junior high school students. Meanwhile the upper limit dimension of seat width is appropriate for the majority of the students. For desk dimension, the desk height is not at the right height for the most students. According to [5], a mismatch in seated elbow height and desk height was significantly related to reported neck and shoulder pain. As for underneath desk height, the dimensions were appropriate for all students both boys and girls of Grades 7-9.

Considering findings in this study, a larger study which involved more samples and covered more geographical areas was recommended. This preliminary review could be a basis for the larger study.

\section{Conclusion}

In this study, the national standard of chair and desk for junior high school level were reviewed. Results showed that mismatches were found between chair and desk dimension with students' anthropometry. The results of this preliminary review could be a basis for a larger study which cover more samples and geographical areas.

The authors would like to thank to the head of the junior high school and students who participated in this study.

\section{References}

1. Castellucci, H., Arezes, P., and Viviani, C., Applied Ergonomics, 41, 563-568, (2010)

2. Castellucci, H.I., Arezes, P.M., and Molenbroek, J.F.M., Applied Ergonomics, 45, 1123-1132 (2014)

3. Castellucci, H.I., Catalan, M., Arezes, P.M., and Molenbroek, J.F.M., International Journal of Industrial Ergonomics, 56, 181 - 188 (2016)

4. Gouvali, M.K., and Boudolos, K., Applied Ergonomics, 37, 765- 773 (2006)

5. Grimes, P., Legg, S., Journal of the Human Environmental System, 7, 1-9 (2004)

6. Milanese, S., and Grimmer, K., Ergonomics, 47, 416-426 (2004)

7. NSAI, SNI 7555.12-2011: Kayu dan produk kayu - Bagian 12: Kursi belajar untuk sekolah menengah pertama, National Standardization Agency of Indonesia, Jakarta, Indonesia (2011a). 
8. NSAI, SNI 7555.11-2011: Kayu dan produk kayu - Bagian 11: Meja belajar untuk sekolah menengah pertama, National Standardization Agency of Indonesia, Jakarta, Indonesia (2011b).

9. Pheasant, S., and Haslegrave, C., Bodyspace: Anthropometry, Ergonomics and Design of Work, Taylor \& Francis, Boca Raton (2006).

10. Parcells, C., Stommel, M., and Hubbard, R.P., Journals of Adolescent Health, 24, 265273 (1999)

11. Panagiotopoulou, G., Christoulas, K., Papanickolaou, A., and Mandroukas, K., Applied Ergonomics, 35, 121-128 (2004)

12. Yanto, Lu, C.W., and Lu, J.M., Applied Ergonomics, 62, 168-181 (2017) 